\title{
Control of Greenhouse Thrips Heliothrips Haemor- rhoidalis (Bouché), with Systemic Insecticides
}

\author{
Silverio Medina Gaud \\ INTRODUCTION
}

The greenhouse thrips, Heliothrips haemorrhoidalis (Bouché), Order Thysanoptera, is a fairly common species in Puerto Rico, although it has a worldwide distribution. Many plants, ornamentals and others, are damaged at times by this thrips. It is very common during dry seasons of the year or under special ecological conditions.

\section{THE INSECT}

\section{DESCRIPTION}

The adult thrips is blackish brown, with light-colored appendages. The head and central portion of the body are covered with a distinct deep network of lines or wartlike elevations. The length of the mature insect is about $1 / 20$ to $1 / 24$ of an inch. The wings are slightly clouded, but without bands, and the antennae are slender and pronouncedly needlelike at the tip. On account of its peculiar markings it is one of the most distinguishable species of thrips and can be easily identified (fig. 1).

The young larva or nymph is white with red eyes, turning yellow when older; the same as the pupae, which also has red eyes. $(4,5)^{2}$

\section{TYPE OF INJURY}

The greenhouse thrips, both the nymph and adult, rasp the surface tissues of the parts of the plants attacked, particularly on the foliage, feeding on the juices thus liberated. As a result of this action, the surface cells die, becoming white in color. This species is found in colonies, all stages being present on the leaves, particularly on the undersides. The peculiar and familiar silvery or bleached appearance quickly becomes evident after feeding has occurred on a leaf. When these insects become abundant they are capable of producing an intense chlorosis of the leaves of the plant attacked, followed by wilting and dropping. The young nymphs excrete from the tip of the abdomen a ball of brown semiliquid material which they carry around, later on depositing it on the feeding surfaces. This secretion gives an unsightly appearance to the foliage and, thus reducing the

1 Research Assistant in Entomology, Department of Entomólogy, Agricultural Experiment Station, Río Piedras, P. R.

2 Italic numbers in parentheses refer to Literature Cited, p. 294. 
commercial value, specially of ornamentals. The black or brownish dots of excrement typical of thrips feeding activity are also a ready means of identifying the injury.

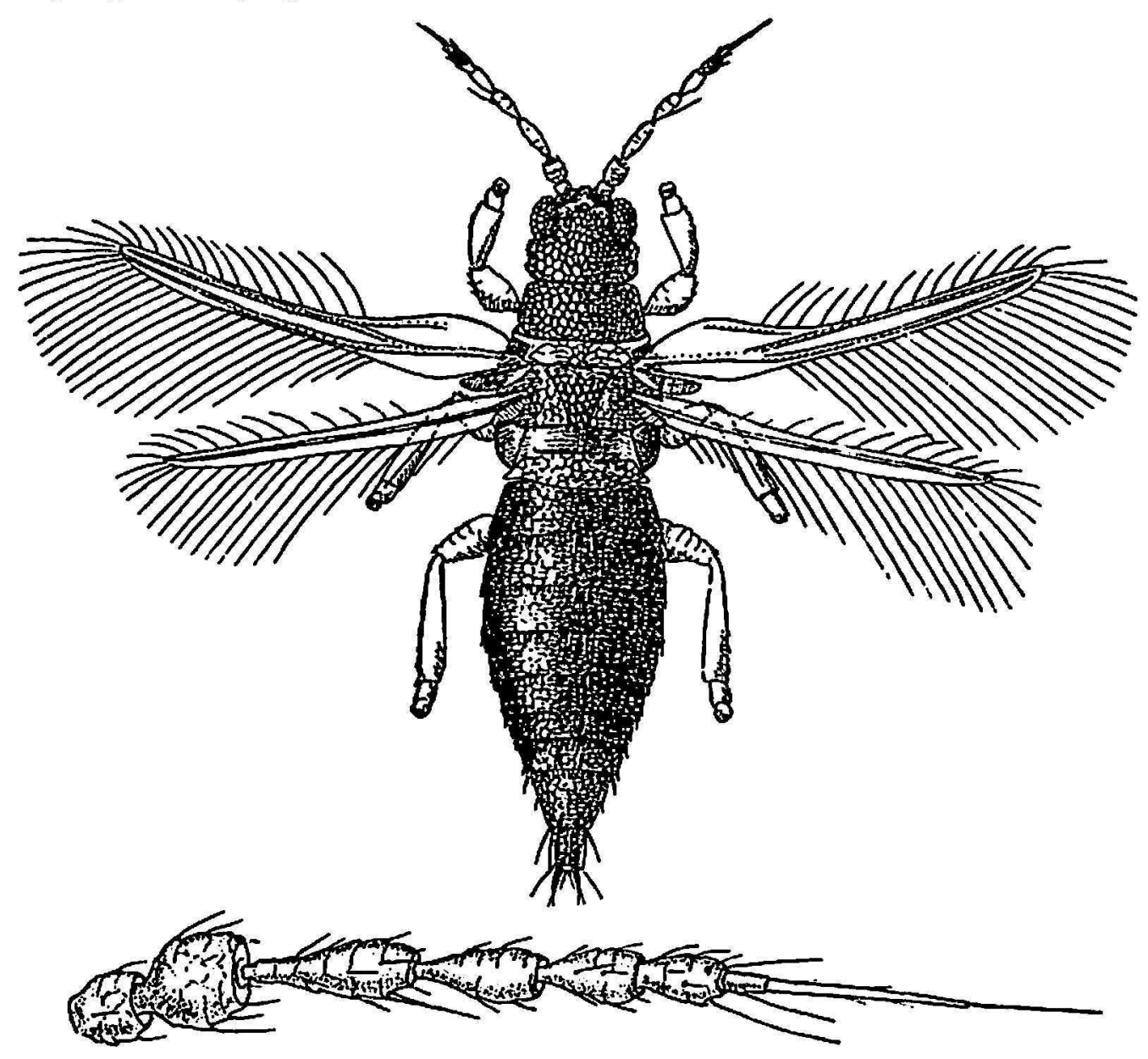

Fig. 1.-Greenhouse thrips, Heliothrips haemorrhoidalis (Bouché). Adult female enlarged about 50 diameters, and greatly enlarged drawing of antenna underneath, (After Russell: USDA Farmers' Bulletin No. 1306, Feb. 23, 1923).

\section{HOSTS}

In Puerto Rico the greenhouse thrips has been listed on the introduced tree, Barringtonia speciosa Forst, and on wild and cultivated cottons, Gossypium hirsutum L. and G. barbadense L.; on cacao, Theobroma cacao L.; grapefruit, Citrus maxima (Burm.) Merril; orange, C. sinensis (L.) Osbeck; and on coconut palm, Cocos nucifera $\mathrm{L}$. It has been reported also as a pest of cinchona, Cinchona calisaya Wedd and C. ledgeriana $(1,2,3,4)$. Three new host records are hereby added. These are "brillantina", Iresine Lindenii Van Houte; croton, Codiaeum variegatum (L.) Blume, and "capa de obispo", Acalypha Wilkesiana Muell. Arg.

\section{MATERIALS AND METHODS}

A control experiment was conducted on August 16, 1957, to evaluate the effectiveness of systemics on the control of the pest. The systemic insecti- 
cides used were: Thimet (47.5 percent, containing 4 pounds of the technical compound per gallon); Systox; Bayer 23129; and Bayer 19639. These last three chemicals contained 2 pounds per gallon of the active ingredient. All the insecticides were used at three concentration levels: $1-400 ; 1-600$; and 1-800.

The test was conducted on croton, Codiaeum variegatum (L.) Blume, heavily infested with the thrips. The croton plants were rooted in sand and then transplanted to 5 -inch clay pots. Four plants, varying in height from 12 to 18 inches, were used for each treatment.

TABLE 1.-Results of the control of Heliothrips haemorrhoidalis Bouché by means of systemic insecticides

\begin{tabular}{|c|c|c|c|c|c|c|c|}
\hline \multirow{4}{*}{$\begin{array}{l}\text { Insecticide } \\
\text { used }\end{array}$} & \multirow{4}{*}{ Dilution } & \multicolumn{6}{|c|}{ Number of live thrips on 12 leaves- } \\
\hline & & \multirow{2}{*}{\multicolumn{2}{|c|}{$\begin{array}{l}\text { Before treament, } \\
\text { Aug. 16, } 1957\end{array}$}} & \multicolumn{4}{|c|}{ After treatment } \\
\hline & & & & \multicolumn{2}{|c|}{ Aug. 20, 1957} & \multicolumn{2}{|c|}{ Oet. 14, 1957} \\
\hline & & Adults & Nymphs & Adults & Nymphs & Adults & Nymphs \\
\hline Thimet, 47.5 percent & $1-400$ & 30 & 61 & 0 & 0 & $\mathbf{0}$ & 0 \\
\hline Do. & $1-600$ & 141 & 126 & 0 & $\mathbf{0}$ & 0 & 0 \\
\hline Do. & $1-800$ & 158 & 117 & $\mathbf{0}$ & 0 & 0 & 0 \\
\hline Systox, 2 lb./gal. & $1-400$ & 9 & 87 & $\mathbf{0}$ & $\mathbf{0}$ & 0 & 0 \\
\hline Do. & $1-600$ & 106 & 116 & $\mathbf{0}$ & 0 & $\mathbf{0}$ & $\mathbf{0}$ \\
\hline Do. & $1-800$ & 70 & 37 & $\mathbf{0}$ & 0 & $\mathbf{0}$ & 0 \\
\hline Bayer 23129, 2 lb./gal. & $1-400$ & 19 & 169 & 0 & $\mathbf{0}$ & 0 & 0 \\
\hline Do. & $1-600$ & 100 & 91 & 0 & 0 & $\mathbf{0}$ & 0 \\
\hline Do. & $1-800$ & 73 & 94 & 0 & 0 & 11 & 0 \\
\hline Bayer 19639, 2 lb./gal. & $1-400$ & 139 & 204 & 0 & 0 & 0 & 0 \\
\hline Do. & $1-600$ & 98 & 160 & 0 & 0 & 0 & 0 \\
\hline Do. & $1-800$ & 58 & 74 & 0 & 0 & 0 & 0 \\
\hline Check (nontreated) & & 104 & 216 & 78 & 120 & 45 & 79 \\
\hline
\end{tabular}

A pretreatment count was conducted on three leaves per plant, making a total of 12 leaves for each treatment. The insecticidal materials were applied as a soil drench, using 5 liquid ounces per pot of the already prepared chemicals at the different levels. Results of the test were determined by counting the number of live thrips on the same leaves selected for pretreatment counts. Weekly counts were continued for 2 months to determine the residual action of the chemicals under test.

\section{RESULTS}

Infestation counts were made on August 16, just before application of insecticides given on the same date. From there on, counts were made on August 20, and thereafter at weekly intervals up to October 14.

As shown in table 1, all insecticidal treatments were effective in con- 
trolling the thrips while the check plants remained infested. It may be noticed that Bayer 23129 compound at a concentration of 1-800 lost its effectiveness at the end of 1 month. All other treatments produced freedom from thrips for 2 months.

Weekly infestation counts after August 20 are not represented in table 1 because no thrips were found until October 14, as shown.

\section{SUMMARY}

The greenhouse thrips, Heliothrips haemorrhoidalis (Bouché) is one of the most common and injurious insect pest of many plants in Puerto Rico. This is specially true during dry seasons and under special ecological conditions. Three new host plants were added to the existing list and the insect is briefly described. Four systemic insecticides were tested namely: Thimet, Systox, Bayer 23129, and Bayer 19639. Using three concentration levels of each chemical perfect control of the thrips was obtained for a period of 2 months, with exception of Bayer 23129 (1-800) which permitted reinfestation at the end of 1 month.

\section{RESUMEN}

El trípido de invernáculo, Heliothrips haemorrhoidalis (Bouché) es uno de los insectos más perjudiciales a muchas plantas en Puerto Rico. Esto es especialmente cierto durante épocas de sequía o bajo condiciones ecológicas especiales. Se incluye una corta descripción del trípido de invernáculo y se añaden tres nuevas plantas hospedadoras a la lista existente.

Cuatro insecticidas sistémicos fueron evaluados, usando tres niveles de concentración. Estos fueron: Thimet, Systox, Bayer 23129, y Bayer 19639. Todos los tratamientos combatieron al trípido eficazmente por un período de dos meses, con la excepción de la concentración de 1-800 del insecticida Bayer 23129. En este último caso las plantas tratadas se reinfestaron al final del primer mes.

\section{LITERATURE CITED}

1. Martorell, L. F., A survey of the forest insects of Puerto Rico, J.Agr. Univ. P.R. $29(4) 367-8,1945$.

2. Moulton, D., Synopsis, Catalogue, and Bibliography of North American Thysanoptera, with Descriptions of New Species, USDA, Tech. Ser. No. 21, 1911.

3. Plank, H. K., and Winters, H. F., Insect and Other Animal Pests of Cinchona and Their Control in Puerto Rico, Bul. 46, pp. 1-16, Fed. Exp. Sta. Mayagüez, P. R., February 1949.

4. Wolcott, G. N., The insects of Puerto Rico, J. Agr. Univ. P. R. $32(1)$ 101, 1948.

5. - Insectae Borinquenses, J. Agr. Univ. P. R. 20 (1) 65, 1936. 